\title{
PENERAPAN PRINSIP PRUDENTIAL DALAM PERKARA PERWALIAN ANAK
}

\author{
Firman Wahyudi*
}

Hakim Pengadilan Agama Nanga Bulik

Jalan Bukit Hibul Timur (Eks Aula BAPPEDA), Komplek Perkantoran Pemda Lamandau Kalimantan Tengah, 74662

\section{Abstract}

Normatively, biological parents' power includes power as guardian for their child, but de facto, when the trusteeship powers intersect with banking practices and the transfer of land rights, the bank and PPAT I Notary still require written documents in the form of court decisions. It aims to provide aspects of legal certainty and is part of the principle of prudence on civil law to avoid all juridical consequences and potential disputes in the future

Keyword: legal certainty, guardianship, prudential principle.

\section{Intisari}

Secara normatif, kekuasaan orang tua kandung meliputi kekuasaan sebagai wali bagi anaknya, namun secara de facto, ketika kekuasaan perwalian ini bersinggungan dengan praktik perbankan dan peralihan hak atas tanah, maka pihak bank dan PPAT/Notaris tetap mensyaratkan adanya dokumen tertulis berupa penetapan pengadilan. Hal ini bertujuan untuk memberikan aspek kepastian hukum dan merupakan bagian dari prinsip kehati-hatian (prudential) dalam lapangan hukum perdata untuk menghindari segala konsekuensi yuridis dan potensi sengketa di kemudian hari.

Kata Kunci: kepastian hukum, perwalian, prinsip kehati-hatian.

\section{Pokok Muatan}

A. Latar Belakang Masalah 369

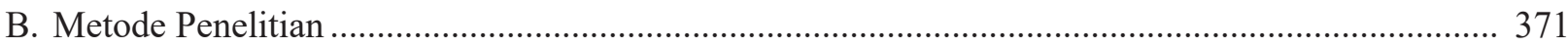

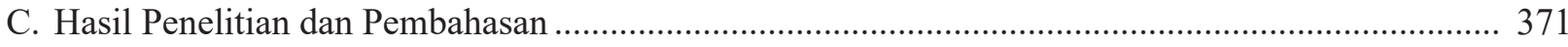

1. Perbedaan Sebab Perwalian Dalam Perspektif KUHPerdata, Undang-Undang Nomor 1 Tahun 1974 tentang Perkawinan, dan Kompilasi Hukum Islam ................................................. 371

2. Urgensi Penetapan Pengadilan (Beschikking) Sebagai Perwujudan Dari Asas Lex Scripta......... 375

3. Penerapan Prinsip Kehati-hatian (Prudential) Dalam Lapangan Hukum Perdata ....................... 377

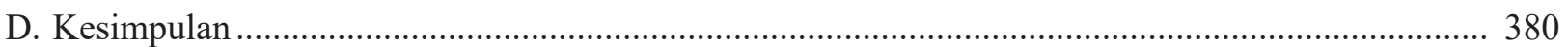

\footnotetext{
Alamat korespondensi: fw.friendly@gmail.com.
} 


\section{A. Latar Belakang Masalah}

Konvensi Anak Sedunia (Convention of The Rights of The Child) pada tanggal 20 November 1989 telah merumuskan beberapa prinsip dan norma universal tentang kedudukan dan hak anak yang kemudian diratifikasi oleh pemerintah Indonesia melalui Keputusan Presiden No 36 tahun 1990 dan Undang-Undang No 23 tahun 2002 tentang Perlindungan Anak yang isunya menekankan tentang pentingnya peran orang tua, masyarakat dan negara dalam melakukan upaya perlindungan dan tanggung jawab terhadap anak. ${ }^{1}$

Dalam konteks Indonesia, anak adalah penerus cita-cita perjuangan bangsa. Selain itu, anak merupakan harapan orang tua dan bangsa yang akan melanjutkan tongkat estafet pembangunan dan kelangsungan eksistensi bangsa. Pada masa pertumbuhan diperlukan pengawasan terhadap anak, karena pada masa anak-anak merupakan periode pembentukan watak, kepribadian dan karakter diri seorang manusia, agar kehidupan mereka memiliki kekuatan dan kemampuan untuk berdiri tegar dalam meniti kehidupan. ${ }^{2}$

Dalam perundang-undangan di Indonesia, pada dasarnya yang berhak dan mempunyai tanggungjawab sebagai wali, mengasuh dan memelihara anak adalah orang tua kandungnya selama keduanya masih cakap melakukan perbuatan hukum. Pasal 47 ayat (1) Undang-Undang Nomor 1 Tahun 1974 tentang Perkawinan (UU Perkawinan) menentukan bahwa anak yang belum berumur 18 tahun atau belum pernah melangsungkan perkawinan berada di bawah kekuasaan orang tua selama kekuasaan orang tuanya belum dicabut. Kemudian dalam ayat (2) dinyatakan bahwa orang tua anak tersebut mewakili kepentingan anak mengenai perbuatan hukum di dalam dan diluar pengadilan. Kedua pasal di atas merupakan dasar hukum kekuasaan orang tua terhadap anak dalam bertindak mewakili kepentingan anak baik di dalam maupun diluar pengadilan.

Ketentuan di atas linier dengan konsep hukum perdata Islam $^{3}$, kekuasaan orang tua bukan hanya bertindak sebatas wali bagi anakanaknya namun lebih dari itu. Orang tua secara moral memiliki tanggungjawab dan kewajiban untuk mengasuh, memelihara dan mendidik anakanaknya sampai dewasa. Kewajiban moral untuk mengasuh dan memelihara anak-anak ini dinamakan dengan hadhanah. Dalam konteks hukum Islam, terminologi hadhanah orang tua terhadap anaknya juga mencakup kekuasaan untuk tampil sebagai wali bagi anak-anaknya baik untuk bertindak di dalam maupun di luar Pengadilan. Pemahaman ini secara mutatis mutandis lahir dari perluasan makna hadhanah itu sendiri yang difahami lebih luas dari hanya sekadar perwalian, karena Perwalian hanya sebatas urusan keperdataan dan tidak mencakup urusan moralitas.

Hal ini berbeda dengan pengaturan kekuasaan orang tua dalam Kitab Undang-Undang Hukum Perdata (KUHPerdata). Kekuasaan orang tua hanya berlaku selama mereka terikat perkawinan dan berakhir apabila perkawinan putus. Dalam hal perkawinan putus, baik karena perceraian atau kematian, maka perihal kewenangan mewakili anak yang belum dewasa masuk dalam ranah hukum perwalian. ${ }^{4}$ Putusnya perkawinan menjadi penyebab berpindahnya hak kekuasaan orang tua menjadi hak perwalian. Menurut Tody Sasmitha, lembaga perwalian (voogdij) merupakan upaya untuk meneruskan kekuasaan orang tua terhadap anak di bawah umur, yang pada saat perwalian tersebut ditetapkan, tidak lagi berada di bawah

Raissa Lestari, “Implementasi Konvensi Internasional Tentang Hak Anak Di Indonesia”, JOM FISIP, Vol. 4, No. 2 , Oktober 2017, hlm 4. Maidin Gultom, 2008, Perlindungan Hukum Terhadap Anak Dalam Sistem Peradilan Pidana Anak Di Indonesia, Refika Aditama, Bandung, hlm 1 .

Jawad Mugniyah, 2000, Fiqh Lima Madzhab, Penerjemah oleh Masykur AB, et al., Lentera Basritama, Jakarta, hlm. 693.

Lihat Pasal 345 KUHPerdata: "Bila salah satu dari orang tua meninggal dunia, maka perwalian anak yang belum dewasa dipangku demi hukum oleh orang tua yang masih hidup sejauh orang tua itu tidak dibebaskan atau dipecat dari kekuasaan orang tua” 
kekuasaan orang tua. ${ }^{5}$

Dalam beberapa kasus, banyak anak-anak di bawah umur yang secara tidak langsung ikut ke dalam interaksi orang tuanya yang masuk kategori perbuatan hukum, seperti mengurus harta warisan orang tuanya yang telah meninggal dunia. Dalam kasus ketika seorang ayah telah meninggal dunia dengan meninggalkan istri dan tiga orang anak yang belum dewasa dan harta warisan berupa sebuah rumah, ibunya kemudian ingin menjual rumah tersebut untuk kepentingan pendidikan anakanaknya, maka berdasarkan ketentuan Pasal 47 ayat (2) UU Perkawinan, ibu selaku orang tua kandung secara otomatis dapat bertindak sebagai wali untuk mengurus kepentingan penjualan rumah tersebut. Menurut hukum positif di atas, kekuasaan orang tua otomatis meliputi kekuasaan perwalian terhadap anak, sehingga secara normatif tidak diperlukan lagi perwalian yang sifatnya penetapan (beschikking), tapi langsung mewakili kepentingan anak untuk bertindak hukum. Namun dalam tataran empiris, hal ini berbeda dengan ketentuan normatif di atas.

Dalam lapangan hukum perdata khususnya yang berkaitan dengan pembuatan akta peralihan hak atau jaminan atas utang, PPAT (notaris) atau pihak perbankan terlebih dahulu mewajibkan orang tua kandung untuk mendapatkan legalitas berupa penetapan perwalian dari pengadilan. Dalam konteks ini orang tua kandung tidak otomatis menjadi wali bagi anak-anaknya, melainkan terlebih dahulu harus ada penetapan dari pengadilan yang menyatakan bahwa orang tua kandung berhak dan layak untuk bertindak hukum terhadap anak-anaknya.

Menarik kiranya mengutip salah satu pertimbangan Majelis Hakim Pengadilan Agama Banjarbaru dalam perkara penetapan perwalian yang mempertimbangkan bahwa meskipun menurut hukum, ayah dan/atau ibu kandung merupakan orang tua sekaligus wali baik terhadap diri maupun harta dari anak-anaknya, namun praktik di lapangan hukum perdata (khususnya dalam dunia perbankan dan peralihan hak atas tanah dan bangunan yang dijalankan di atas prinsip atau asas prudential) tetap mensyaratkan adanya bukti tertulis (lex scripta) atas suatu alas hak atau hubungan hukum, sehingga pada keadaan demikian, orang tua kandung sekalipun perlu mendapatkan penetapan dari pengadilan atas keabsahannya sebagai wali dari anak kandungnya sendiri. ${ }^{6}$

Secara normatif memang orang tua kandung merangkap peran sebagai wali dari anak-anak mereka yang di bawah umur, namun dalam praktik lapangan $\mathrm{h}$ ukum perdata yang bersinggungan langsung dengan dunia perbankan dan peralihan hak atas tanah yang menyangkut pihak ketiga perlu dipastikan tentang kondisi dan keadaan orang tua tidak dalam keadaan pailit dan tidak di bawah pengampuan (idiot) karenanya demi kepastian hukum dan untuk menghindari hal-hal yang merugikan hak anak dan pihak ketiga, maka dalam hal ini perlunya alas hukum berupa sebuah penetapan (beschikking) dari pengadilan. ${ }^{7}$

Berdasarkan hal tersebut, yang menjadi isu penting dalam kajian ini adalah adanya kesenjangan pengaturan antara de jure dan de facto mengenai kekuasaan orang tua kandung yang sekaligus menjadi wali bagi anaknya menurut UU Perkawinan dengan praktik dalam lapangan hukum perdata yang tetap mensyaratkan adanya bukti hukum tertulis dari pengadilan atas perwalian tersebut.

Berdasarkan latar belakang di atas, maka ada beberapa masalah fundamental yang perlu untuk dikaji di antaranya tentang: Pertama, Apa implikasi perbedaan sebab perwalian dalam perspektif KUHPerdata, UU Perkawinan dan KHI? Kedua, Bagaimana urgensi penetapan pengadilan dalam perkara perwalian orang tua kandung terhadap anak? Ketiga, Bagaimana implementasi

Tody Sasmitha, Hukum Perkawinan dan Keluarga, dalam Ahmadi Miru, (tanpa tahun), Hukum Perdata Materiil dan Formil, USAID, Jakarta, hlm. 71.

Lihat Penetapan No 0021/Pdt.P/2014/PA.Bjb tanggal 16 April 2014.

Teddy Lahati, "Penetapan Voogdij Bagi Orang Tua", https://badilag.mahkamahagung.go.id/artikel/publikasi/artikel/penetapan-voogdij-bagiorang-tua-oleh-teddy-lahati-20-10, diakses 5 Agustus 2019. 
prinsip prudential dalam perkara perwalian anak terkait dengan peralihan hak atas tanah dan jaminan perbankan?

\section{B. Metode Penelitian}

Penelitian tentang penerapan prinsip prudential dalam perkara perwalian anak merupakan jenis penelitian hukum normatif. Penelitian hukum normatif adalah suatu penelitian hukum terhadap aturan-aturan, norma, dan asas-asas hukum. Menurut Soerjono Soekanto penelitian hukum normatif diarahkan pada penelitian yang menarik asas-asas hukum, sistematika hukum, sinkronisasi peraturan perundang-undangan, perbandingan hukum, dan sejarah hukum. ${ }^{8}$

Bahan hukum yang digunakan dalam penelitian ini terbagi menjadi tiga yaitu bahan hukum primer, sekunder dan tersier. Bahan hukum primer berupa sejumlah legislasi dan putusan pengadilan yang bersinggungan dengan topik penelitian di antaranya KUHPerdata, Undang-Undang Nomor 1 Tahun 1974 tentang Perkawinan, Undang-Undang Nomor 10 Tahun 1998 tentang Perbankan, UndangUndang Nomor 21 Tahun 2008 tentang Perbankan Syariah, Peraturan Pemerintah Nomor 24 Tahun 2016 atas Perubahan Peraturan Pemerintah Nomor 37 Tahun 1998 tentang Peraturan Pejabat Pembuat Akta Tanah, Kompilasi Hukum Islam (KHI), dan Putusan Pengadilan Agama Banjarbaru No 0021/ Pdt.P/2014/PA.Bjb. Adapun bahan hukum sekunder meliputi beberapa referensi hukum yang tidak termasuk dalam dokumen resmi negara seperti buku, disertasi, tesis dan beberapa jurnal yang berhubungan dengan tema penelitian. Disamping itu untuk melengkapi kedua bahan hukum di atas diperlukan beberapa istilah asing (bahasa hukum) yang termuat dalam beberapa kamus dan ensiklopedia mengenai topik penelitian sebagai bagian dari bahan hukum tersier.

Pendekatan yang digunakan dalam penelitian ini adalah berbasis konseptual (conceptual approach). Pendekatan konseptual adalah berusaha membangun argumentasi yang utuh tentang sebuah prinsip/asas hukum baik dengan menyempurnakan konsep yang sudah ada maupun yang belum ada. Adapun metode yang digunakan adalah deskriptif analitik dengan cara memaparkan dan menganalisa seluruh sumber hukum di atas kemudian mengidentifikasi dan menemukan asas-asas hukum yang terkandung dalam beberapa peraturan terkait sehingga peneliti akan menemukan sebuah konsep/ asas hukum yang relevan dengan isu yang sedang dihadapi.

\section{Hasil Penelitian dan Pembahasan \\ 1. Perbedaan Sebab Perwalian Dalam Perspektif KUHPerdata, Undang-Undang Nomor 1 Tahun 1974 tentang Perkawinan, dan Kompilasi Hukum Islam}

Dalam Islam, perwalian secara etimologi berasal dari kata wali, dan jamak "awliya". Kata ini berasal dari bahasa Arab yang berarti "teman", "klien", "sanak", "pelindung". 9 Umumnya kata tersebut menunjukkan arti "sahabat Allah" dalam frase waliyullah. Dalam konteks al-Qur'an makna wali juga mengandung arti sebagai penolong. ${ }^{10}$ Sedangkan dalam terminologi fikih disebut dengan al-wilayah yang berarti penguasaan dan perlindungan.

Adapun dalam pengertian umum fikih, perwalian ialah penguasaan penuh yang diberikan oleh agama kepada seseorang untuk menguasai dan melindungi orang atau barang. Orang yang diberi kekuasaan perwalian disebut wali. ${ }^{11}$ Oleh karena itu perwalian adalah suatu kewenangan yang diberikan kepada seseorang untuk melakukan suatu perbuatan

Soerjono Soekanto, 2007, Pengantar Penelitian Hukum, UI Press, Jakarta, hlm. 51.

Lihat YourDictionary, "Glossary of the Middle East: Glossary of Islam", https://grammaryourdictionary.com/glossaries/global-counterrorism/ islam.html, diakses 30 Oktober 2019.

10 Dalam QS. At-Taubah, ayat 71 dinyatakan: "Dan orang-orang yang beriman, laki-laki dan perempuan, sebagian mereka (adalah) menjadi penolong bagi sebagian yang lain.

11 Soemiyati, 1986, Hukum Perkawinan dan Undang-Undang Perkawinan (Undang-Undang No. 1 Tahun 1974 tentang Perkawinan), Liberty, Yogyakarta, hlm. 41. 
hukum sebagai wakil untuk kepentingan dan atas nama anak yang tidak mempunyai kedua orang tua atau orang tuanya masih hidup tetapi tidak cakap melakukan perbuatan hukum.

Perwalian menurut hukum Islam merupakan tanggungjawab orang tua terhadap anak. Dalam hukum Islam diatur dalam hadhanah yang diartikan melakukan pemeliharaan anak-anak yang masih kecil, laki-laki atau perempuan atau yang sudah besar tetapi belum tamyiz dan menyediakan sesuatu yang menjadikan kebaikannya, menjaganya dari sesuatu yang menyakiti dan merusaknya, mendidik jasmani, rohani dan akalnya agar mampu berdiri sendiri menghadapi hidup dan memikul tanggungjawabnya. ${ }^{12}$

Sebelum perwalian timbul, maka anak berada di bawah kekuasaan orang tua yang merupakan kekuasaan yang dilakukan oleh ayah atau ibu, selama ayah atau ibu masih terikat dalam perkawinan. Kekuasaan itu biasanya dilakukan oleh ayah, namun jika ayah berada diluar kemungkinan untuk melakukan kekuasaan tersebut maka ibu yang menjadi wali. Pada umumnya kedua orang tua wajib memelihara dan mendidik anak-anak yang belum dewasa, meskipun orang tua dari anak yang belum dewasa tersebut kehilangan hak menyelenggarakan kekuasaan orang tua atau menjadi wali, hal itu tidak membebaskan orang tua si anak dari kewajiban untuk memberikan tunjangan membayar pemeliharaan atau pendidikannya sampai anak tersebut dewasa.

Dari sudut pandang hukum Islam, perwalian terbagi menjadi 3 bagian yaitu pertama, perwalian terhadap jiwa (al-walayah 'alan nafs), kedua, perwalian terhadap harta (al-walayah 'alalmal), dan ketiga, perwalian terhadap jiwa dan harta (al-walayah 'alan nafs wal mali ma'an). Perwalian dalam nikah tergolong ke dalam alwalayah 'alan nafs yaitu perwalian yang bertalian dengan pengawasan (al-Isyraf) terhadap urusan yang berhubungan dengan masalah-masalah seperti perkawinan, pemeliharaan dan pendidikan anak, kesehatan dan aktivitas anak yang hak kepengawasan pada dasarnya berada di tangan ayah, kakek atau para wali lainnya. Adapun perwalian terhadap harta adalah perwalian yang berhubungan dengan ihwal pengelolaan kekayaan tertentu dalam hal pengembangan, pemeliharaan, pengawasan dan pembelanjaan. Sedangkan perwalian terhadap jiwa dan harta adalah perwalian yang meliputi urusan pribadi dan harta kekayaan secara bersamaan dan hanya berada ditangan ayah dan kakek. ${ }^{13}$

Dalam KUHPerdata, pengaturan perwalian tercantum dalam Buku ke-I, Bab XV, bagian kedua sampai dengan bagian ketiga belas, mulai Pasal 331 sampai dengan Pasal 418a. Menurut Titik Triwulan Tutik, anak yang berada di bawah perwalian yaitu anak yang belum dewasa dan salah satu atau kedua orang tuanya telah meninggal dunia, orang tuanya telah bercerai atau anak yang lahir di luar kawin. ${ }^{14}$ Sedangkan menurut Subekti, anak, yang berada di bawah perwalian yaitu: Pertama, anak sah yang orang tuanya telah meninggal dunia salah satu atau keduanya. Kedua, anak sah yang kedua orang tuanya telah dicabut kekuasaan sebagai orang tua. Ketiga, anak sah yang orang tuanya telah bercerai. Keempat, anak yang lahir di luar perkawinan. ${ }^{15}$

Berdasarkan uraian di atas dapat dipahami bahwa menurut KUHPerdata sebab-sebab anak berada di bawah perwalian adalah karena orang tuanya telah bercerai, orang tuanya telah meninggal dunia, pencabutan kekuasaan orang tua atau karena anak tersebut lahir sebelum perkawinan atau setelah perkawinan bubar baik karena perceraian, meninggal salah satu pihak atau karena pembatalan perkawinan.

Perwalian menurut hukum perdata terdiri dari 3 (tiga) macam, yaitu: Pertama, perwalian menurut undang-undang (wettelijke voogdij) yaitu perwalian

\footnotetext{
Sayid Sabiq, 1980, Fiqih Sunah: Jilid ke-8, Al Maarif, Bandung, hlm. 173.

Muhammad Amin Suma, 2005, Hukum Keluarga Islam di Dunia Islam, PT. Raja Grafindo Persada, Jakarta, hlm. 136.

Titik Triwulan Tutik, 2006, Pengantar Hukum Perdata di Indonesia, Prestasi Pustaka, Surabaya, hlm. 91.

Subekti, 2003, Pokok-Pokok Hukum Perdata, Intermasa, Jakarta, hlm. 53.
} 
oleh orang tua yang masih hidup setelah salah seorang meninggal dunia terlebih dahulu (Pasal 345 KUHPerdata). Kedua, perwalian karena wasiat orang tua (testtamentair voogdij) yaitu perwalian yang dengan surat wasiat oleh salah seorang dari orang tuanya (Pasal 355 KUH Perdata). Ketiga, perwalian yang ditunjuk oleh hakim (datieve voogdij) (Pasal 359 KUH Perdata). ${ }^{16}$

Perwalian menurut undang-undang yaitu jika salah satu dari orang tua meninggal dunia, maka perwalian demi hukum dilakukan oleh orang tua yang hidup. Perwalian dengan wasiat yaitu tiap orang tua yang melakukan kekuasaan orang tua, berhak mengangkat seorang wali bagi anak jika ia meninggal dunia. Perwalian datif yaitu apabila tiada wali menurut undang-undang atau wali dengan wasiat, maka oleh hakim ditetapkan seorang wali. ${ }^{17}$

Dalam konteks UU Perkawinan, anak tidak berada di bawah kekuasaan orang tua karena: Pertama, orang tua telah meninggal dunia keduaduanya. Kedua, orang tua kedua-duanya tidak cakap melakukan tindakan hukum dan ketiga orang tua dicabut kekuasaannya. Lebih lanjut, Pasal 51 UU Perkawinan menentukan bahwa wali dapat ditunjuk oleh orang tua yang menjalankan kekuasaan orang tua dengan surat wasiat atau lisan dihadapan 2 (dua) orang saksi. Apabila diperhatikan sebab-sebab berada di bawah perwalian dan juga ketentuan Pasal 51 UU Perkawinan, maka dapat dipahami bahwa UU Perkawinan, selain mengenal perwalian dengan surat wasiat atau secara lisan, juga mengenal perwalian yang ditunjuk oleh hakim. Akan tetapi UU Perkawinan, tidak mengenal jenis perwalian menurut undang-undang. Menurut UU Perkawinan, perceraian orang tua tidak mengakibatkan anak yang belum berumur 18 tahun atau belum kawin berada di bawah perwalian, anak tersebut tetap berada dalam kekuasaan salah seorang orang tuanya. Demikian pula halnya untuk anak di luar kawin, maka anak tersebut berada dalam kekuasaan orang tua yaitu ibunya.

Menurut konsep UU Perkawinan, putusnya perkawinan orang tua, baik karena meninggal salah satu orang tua atau pembatalan perkawinan ataupun perceraian tidak mengakibatkan anak berada di bawah perwalian. Dalam Pasal 41 huruf a ditentukan baik ibu atau bapak tetap berkewajiban memelihara dan mendidik anak-anaknya sematamata berdasarkan kepentingan anak-anak, bila ada perselisihan mengenai penguasaan anak-anak maka pengadilan memberi putusan.

Apabila terjadi perselisihan mengenai penguasaan anak, maka keputusan atas hak penguasaan ditentukan oleh pengadilan dengan memperhatikan usia dan kepentingan anak. Pada umumnya jika anak masih di bawah umur (kecil), maka hak pemeliharaan (pengasuhan) diserahkan pada ibu, sedangkan ayah diberi kewajiban beban untuk menanggung biaya pemeliharaan anak sebagai bentuk tanggung jawabnya. ${ }^{18}$

Adapun dalam KHI pengaturan perwalian di atur dalam Buku ke-I, Bab XV, mulai Pasal 107 sampai dengan Pasal 112. Menurut ketentuan Pasal 107 ayat (1), perwalian hanya terhadap anak yang belum mencapai umur 21 tahun dan atau belum pernah melangsungkan perkawinan. Selanjutnya dalam ayat (2) ditentukan perwalian meliputi perwalian terhadap diri dan harta kekayaannya. Apabila dilihat dari umur anak yang berada di bawah perwalian yaitu belum berumur 21 tahun, maka ketentuan tersebut sama dengan ketentuan dalam KUHPerdata, akan tetapi berbeda dengan ketentuan UU Perkawinan yaitu belum berumur 18 tahun.

Apabila dilihat pada ketentuan Pasal 1 huruf $\mathrm{h}$ KHI, maka dapat dipahami bahwa sebabsebab berada di bawah perwalian yaitu: Pertama, anak yang tidak mempunyai kedua orang tuanya.

\footnotetext{
Titik Triwulan Tutik, Op.cit., hlm. 93.

Ali Afandi, 2000, Hukum Waris, Hukum Keluarga Hukum Pembuktian, Rineka Cipta, Jakarta, hlm. 157.

Bernadetta T. Wulandari, "Posisi Anak dalam Perkawinan Antar Bangsa dan Berbagai Permasalahan Hukumnya", Jurnal Hukum, Vol. 7, No. 1, Januari-April 2007, hlm. 79.
} 
Kedua, anak yang kedua orang tuanya masih hidup, tetapi tidak cakap melakukan tindakan hukum. Ketiga, anak berada di bawah perwalian juga dapat disebabkan jika kedua orang tua dicabut kekuasaan orang tuanya. Pencabutan dilakukan oleh Pengadilan Agama yang berwenang atas permintaan keluarga dalam garis lurus ke atas, saudara kandung yang sudah dewasa atau pejabat yang berwenang karena kedua orang tua melalaikan kewajiban atau berkelakuan buruk terhadap anak. Menurut ketentuan Pasal 108 KHI, orang tua dapat mewasiatkan kepada seseorang atau badan hukum untuk melakukan perwalian terhadap diri dan kekayaan anaknya sesudah ia meninggal dunia. ${ }^{19}$

Tabel 1.

Perbedaan Perwalian Dalam Perspektif Hukum Islam dan Hukum Tertulis

\begin{tabular}{|c|c|c|c|}
\hline No Sumber Hukum & Jenis-jenis Perwalian & Sebab-sebab Perwalian & Dasar \\
\hline 1. Hukum Islam & $\begin{array}{l}\text { 1. Perwalian Terhadap jiwa } \\
\text { 2. Perwalian terhadap harta } \\
\text { 3. Perwalian terhadap jiwa } \\
\text { dan harta }\end{array}$ & & $\begin{array}{l}\text { QS.Al-Baqarah: } \\
282 \\
\text { Q.S. An-nisa : } \\
\text { 5-6 }\end{array}$ \\
\hline 2. $\quad$ KUHPerdata & $\begin{array}{l}\text { 1. Perwalian menurut Undang- } \\
\text { Undang } \\
\text { 2. Perwalian karena wasiat } \\
\text { orang tua } \\
\text { 3. Perwalian datif(ditunjuk } \\
\text { hakim) }\end{array}$ & $\begin{array}{l}\text { 1. Perceraian orang tua } \\
\text { 2. Meninggalnya salah satu } \\
\text { dari orang tua } \\
\text { 3. Pencabutan kekuasaan } \\
\text { orang tua } \\
\text { 4. Kelahiran anak sebelum } \\
\text { atau setelah perkawinan } \\
\text { bubar baik karena } \\
\text { perceraian, meninggal salah } \\
\text { satu pihak atau pembatalan } \\
\text { perkawinan }\end{array}$ & $\begin{array}{l}\text { Buku ke-I Bab } \\
\text { XV Pasal 331- } \\
418\end{array}$ \\
\hline 3. UU No.1/1974 & $\begin{array}{l}\text { 1. Perwalian dengan lisan } \\
\text { atau surat wasiat } \\
\text { 2. Perwalian yang ditunjuk } \\
\text { hakim }\end{array}$ & $\begin{array}{l}\text { 1. Orang tua telah meninggal } \\
\text { kedua-duanya } \\
\text { 2. Kedua orang tua tidak } \\
\text { cakap melakukan tindakan } \\
\text { hukum } \\
\text { 3. Orang tua dicabut } \\
\text { kekuasaannya }\end{array}$ & \\
\hline 4. $\mathrm{KHI}$ & $\begin{array}{l}\text { 1. Perwalian terhadap anak di } \\
\text { bawah umur } 21 \text { tahun } \\
\text { 2. Perwalian terhadap diri } \\
\text { dan harta anak }\end{array}$ & $\begin{array}{l}\text { 1. Anak yang tidak } \\
\text { mempunyai kedua orang } \\
\text { tua } \\
\text { 2. Kedua orang tua tidak } \\
\text { cakap melakukan tindakan } \\
\text { hukum } \\
\text { 3. Orang tua dicabut } \\
\text { kekuasaannya }\end{array}$ & $\begin{array}{l}\text { Buku ke-I Bab } \\
\text { XV Pasal 107- } \\
112\end{array}$ \\
\hline
\end{tabular}

Sumber: Diolah oleh Penulis, 2019.

19 Ishak, "Perwalian Menurut Konsep Hukum Tertulis", Kanun Jurnal Ilmu Hukum, Vol. 19, No. 3, Agustus 2017 , hlm. 580. 
Berdasarkan ketentuan perwalian dan tabel di atas, ada satu perbedaan paling mendasar sehubungan dengan kajian ini yaitu perwalian menurut undang-undang (wettelijke voogdij). Dari pembacaan pada pasal-pasal KUHPerdata di atas menunjukan bahwa kekuasaan orang tua hanya berlaku selama mereka terikat perkawinan dan berakhir apabila perkawinan putus. Dalam hal perkawinan putus, maka kewenangan mewakili anak yang belum dewasa masuk dalam ranah perwalian dan orang tua tersebut berkedudukan sebagai wali.

Hal ini berbeda dengan UU Perkawinan dan KHI. Kedua peraturan ini tidak mengenal kedudukan sebagai wali oleh ayah atau ibu kandung. Tidak terdapat klausul yang menyebutkan bahwa kekuasaan orang tua berakhir akibat putusnya perkawinan dan selanjutnya orang tua berkedudukan sebagai wali dalam hal mewakili kepentingan anaknya yang belum dewasa. Dengan kata lain, tidak ada satu pun pasal atau ayat yang mengandung norma mengakhiri kekuasaan orang tua lalu mengalihkannya dalam bagian hukum perwalian sebagai akibat putusnya perkawinan. Dalam hal ini, UU Perkawinan dan KHI tidak lagi mengenal salah satu dari orang tua yang berkedudukan sebagai wali atau dengan kata lain seseorang yang berkedudukan sebagai wali harus berasal dari orang lain, sehingga harus dipahami bahwa kekuasaan orang tua tetap berlangsung meskipun perkawinannya putus. Oleh karena itu terminologi perwalian sudah terpisah secara tegas.

Menurut penulis, adanya perbedaan sebab perwalian antara hukum positif (baca: UU Perkawinan dan KHI) dengan KUHPerdata tentang jenis perwalian menurut undang-undang (wettelijke voogdij) inilah yang menyebabkan lahirnya dualisme kekuasaan yaitu kekuasaan sebagai orang tua dan kekuasaan sebagai wali. Dalam kasus ketika salah satu dari kedua orang tua meninggal dunia atau bercerai, pihak Bank dan PPAT/Notaris lebih berpedoman pada konsep perwalian menurut Undang-Undang dalam perspektif KUHPerdata daripada konsep perwalian menurut UU Perkawinan dan KHI, sehingga secara hukum kekuasaan orang tua berubah fungsinya menjadi wali.

Adanya perubahan terminologi kekuasaan dari yang semula orang tua menjadi wali, tentunya menjadi diskursus tersendiri dan perlu kajian lebih mendalam. Di satu sisi perubahan terminologi ini mereduksi kekuasaan mutlak orang tua sebagaimana yang diberikan UndangUndang, namun di sisi lain perubahan terminologi ini dalam rangka memberikan aspek kepastian hukum dan membangun asas prudential (kehatihatian) dalam lapangan hukum perdata terlebih jika hubungan hukum antara orang tua dan anak tersebut bersinggungan langsung dengan pihak ketiga.

\section{Urgensi Penetapan Pengadilan (Beschik- king) Sebagai Perwujudan Dari Asas Lex Scripta}

Pada dasarnya, produk sebuah Pengadilan hanya ada dua macam yaitu putusan (vonnis) dan penetapan (beschikking). Putusan dikeluarkan untuk mengakhiri sebuah sengketa di antara pihak-pihak yang berlawanan (contentiosa).${ }^{20}$ Rumusan amarnya bersifat condemnatoir yaitu berupa menghukum salah satu pihak untuk melaksanakan isi putusan. Sedangkan penetapan bersifat voluntair ${ }^{21}$ dan hanya dihadiri satu pihak saja yaitu pemohon (exparte), amar putusannya bersifat deklaratoir yang berisi penegasan pernyataan atau deklarasi hukum (penetapan) tentang hal yang diminta.

Untuk menentukan sebuah perkara itu tergolong voluntair harus diatur terlebih dahulu oleh sebuah undang-undang. Pengadilan tidak bisa menetapkan begitu saja sebuah perkara yang diajukan para pihak sementara hal itu tidak ditentukan oleh suatu undang-undang. Menurut Yahya Harahap, sebuah kompetensi/kewenangan dalam mengadili dan menyelesaikan sebuah 
perkara terbatas pada hal-hal yang tegas ditentukan oleh peraturan perundang-undangan, dengan kata lain Pengadilan tidak boleh mengadili sebuah perkara yang hal itu nyata-nyata tidak diatur oleh Undang-Undang. ${ }^{22}$ Perlu diingat bahwa pendapat ini diambil berdasarkan ketentuan Pasal 2 UndangUndang Nomor 14 Tahun 1970 tentang Kekuasaan Kehakiman. ${ }^{23}$

Permohonan penetapan perwalian orang tua kandung terhadap anak termasuk salah satu jenis perkara voluntair yang diajukan ke Pengadilan dengan tujuan untuk mendapatkan legalitas hukum terkait kewenangan orang tua terhadap anaknya dalam bertindak hukum mewakili kepentingan anak baik terhadap diri maupun hartanya di dalam ataupun di luar pengadilan. Kewenangan ini diatur lebih lanjut dalam Pasal 49 UndangUndang Nomor 3 Tahun 2006 tentang Perubahan Atas Undang-Undang Nomor 7 tahun 1989 tentang Peradilan Agama pada bab perkawinan yang dirinci menjadi 22 item ${ }^{24}$ dan salah satunya adalah tentang perwalian. ${ }^{25}$

Secara umum produk pengadilan yang sifatnya voluntair (penetapan/beschikking) adalah bertujuan untuk memberikan bentuk kepastian hukum dan perlindungan kepada para pihak dan dengan sendirinya bernilai sebagai akta otentik. ${ }^{26}$ Doktrin ini sesuai dengan ketentuan yang digariskan Pasal 1868 KUHPerdata yang menyatakan:

"Suatu akta otentik ialah suatu akta yang dibuat dalam bentuk yang ditentukan oleh Undang-Undang, oleh atau dihadapan Pegawai umum yang berkuasa untuk itu di tempat akta itu dibuat". ${ }^{27}$

Lebih lanjut Yahya Harahap menjelaskan bahwa fungsi tulisan atau akta dari segi hukum pembuktian ialah sebagai formalitas kausa, alat bukti, dan berfungsi sebagai robationis causa. Fungsi suatu akta sebagai formalitas kausa ialah sebagai syarat atas keabsahan suatu tindakan hukum yang dilakukan. Apabila perbuatan atau tindakan hukum yang dilakukan tidak sesuai dengan surat atau akta, tindakan itu menurut hukum tidak sah, karena tidak memenuhi formalitas kausa (causa).

Adapun fungsi akta sebagai alat bukti ialah sebagaimana disebutkan Pasal 1864 KUHPerdata sendiri yang telah menetapkannya sebagai alat bukti pada urutan pertama. Memang tujuan utama membuat akta diperuntukkan dan digunakan sebagai alat bukti. Terakhir ialah akta berfungsi sebagai robationis causa, maksudnya surat atau akta yang bersangkutan merupakan satu-satunya alat bukti yang dapat dan sah membuktikan suatu hal atau peristiwa tertentu ${ }^{28}$.

Berdasarkan sifat-sifat di atas, maka pada diri penetapan (beschikking) itu melekat nilai kekuatan pembuktian yang sempurna dan melekat (volledig en bindende bewijskracht). Pembuktian yang sempurna dan melekat di sini mengandung makna, bahwa setiap produk penetapan Pengadilan bertujuan untuk memberikan nilai kepastian hukum dan sebagai dasar bukti tertulis yang bisa dipergunakan untuk bertindak hukum mengurus kepentingan hak-hak keperdataannya terlebih lagi jika hak-hak tersebut berkaitan erat dengan transaksi perbankan atau menyangkut suatu peralihan hak atas tanah dan bangunan. ${ }^{29}$

Menyinggung pentingnya bukti tertulis sebagai bagian dari asas legalitas (lex scripta) tentunya tidak terlepas dari unsur kepastian hukum

Yahya Harahap, 2008, Hukum Acara Perdata Tentang Gugatan, Persidangan, Penyitaan, Pembuktian dan Putusan Pengadilan, Sinar Grafika, Jakarta, hlm. 30.

23 Bunyi Pasal 2 ayat (2) "Tugas lain dari pada yang tersebut pada ayat (1) dapat diberikan kepadanya berdasarkan peraturan perundangundangan." Namun berdasarkan Undang-Undang Kekuasaan Kehakiman yang terakhir yakni Undang-Undang Nomor 48 Tahun 2009 tentang Kekuasaan Kehakiman, pengaturan seperti itu sudah tidak dicantumkan lagi.

24 Perwalian diatur pada angka 15,16,17,18 dan 19 Penjelasan atas Undang-Undang ini.

Amran Suadi, 2017, Penyelesaian Sengketa Ekonomi Syariah Teori dan Praktik, Penerbit Kencana, Jakarta, hlm. 38.

Yahya Harahap, Op. cit., hlm. 41

Pasal 1868 Kitab Undang-Undang Hukum Perdata.

Fernando Kubis, "Kekuatan Pembuktian Surat Menurut Hukum Acara Perdata", Jurnal Lex Crimen, Vol. 6, No.5, Juli 2017, hlm. 108-109.

Legal Consultant Shietra and Fatners, "Penetapan Wali Anak Di Bawah Umur Oleh Orang Tua", https://www.hukum-hukum.com/2016/11/ penetapan-wali-anak-dibawah-umur-terkait-tanah.html, diakses 7 agustus 2019. 
itu sendiri. Menurut doktrin ilmu hukum, lex scripta diambil dari nilai-nilai tertentu yang menjadi panutan hidup yang berlaku dalam masyarakat atau dalam suatu komunitas tertentu. Hanya normatifitas keberlakuannya oleh negara diresmikan atau diformalkan melalui (pembentukan) undangundang. Akan tetapi, jika ada nilai-nilai sosial lainnya yang secara formal tidak ditetapkan dan tidak diberlakukan sebagai kaidah hukum dalam undang-undang, maka nilai-nilai sosial tersebut tidak dipandang sebagai suatu kaidah hukum. Oleh karena itu asas hukum yang ditimbulkan dari lex scripta adalah asas legalitas formal, mengingat ketertiban untuk mencapai keadilan diformulasikan dalam suatu kaidah hukum yang ditetapkan keberlakuannya melalui sarana hukum berupa undang-undang, sehingga lebih memiliki nilai kepastian hukum dan keadilan yang hendak dicapainyapun keadilan menurut undang-undang (keadilan formal). ${ }^{30}$

Apabila ditinjau dari salah satu teori yang digunakan dalam asas ini adalah teori kepastian hukum. Kepastian hukum adalah ketika suatu peraturan dibuat dan diundangkan secara pasti karena mengatur secara jelas dan logis. Jelas dalam artian tidak menimbulkan keraguan (multitafsir) dan logis dalam artian ia menjadi suatu sistem norma dengan norma lain sehingga tidak berbenturan. Kepastian hukum adalah kepastian aturan hukum, bukan kepastian tindakan yang sesuai dengan aturan hukum. Karena frasa kepastian hukum tidak mampu menggambarkan kepastian perilaku terhadap hukum secara benar-benar. ${ }^{31}$

Penetapan pengadilan (beschikking) adalah bagian dari ikhtiar untuk mewujudkan asas kepastian hukum itu sendiri. Dengan adanya penetapan sebagai produk pengadilan akan dapat menjembatani kesenjangan antara normatifitas teks undang-undang dengan realitas konteks masyarakat modern serta melahirkan sebuah norma yang tadinya bersifat abstrak menjadi norma yang berwujud konkrit. Disinilah letak pentingnya penetapan pengadilan sebagai bentuk perwujudan dari asas hukum tertulis (lex scripta) untuk memberikan unsur kepastian hukum dalam bentuk legalitas formal kepada para pihak. Penetapan yang berbentuk legalitas formal ini bisa dijadikan sebagai alas hukum untuk bertindak dalam lapangan hukum keperdataan khususnya yang bersinggungan dengan jaminan perbankan, maupun suatu peralihan hak atas tanah dan bangunan seperti jual beli dengan pihak ketiga.

\section{Penerapan Prinsip Kehati-hatian (Pruden- tial) Dalam Lapangan Hukum Perdata}

Secara umum prinsip kehati-hatian dapat diartikan sebagai dasar tentang kebenaran yang menjadi landasan berpikir dan bertindak dengan penuh sikap hati-hati. ${ }^{32}$ Prinsip kehati-hatian merupakan pengembangan dari prinsip prudence. Dalam Black's Law Dictionary kata "prudence" didefinisikan sebagai berikut :

"Carefulnees, precaution, attentiveness and good judgment, as applied to action or of care reconduct.That degree of care required by the exigencies or circumstances under which it is to be exercised. This trem, in the language of the law, is commonly associated with care and diligence as constrasted with negligence". ${ }^{33}$

Definisi tersebut diterjemahkan bebas dengan: "Ketelitian, pencegahan, perhatian dan penilaian obyektif seperti yang terkandung dalam aksi atau kepedulian. Tingkat kepedulian tersebut membutuhkan urgensi atau suatu keadaan yang membutuhkan banyak pelatihan. Kondisi ini dalam bahasa hukum diasosiasikan dengan kepedulian dan

\footnotetext{
30 A.Widiada Gunakaya, "Kedudukan "Lex Ne Scripta” Dalam Sistem Hukum Indonesia”, Jurnal Wawasan Hukum, Vol. 22, No. 01, Februari 2010, hlm. 9.

31 Elvita Savira, et al., "Penetapan Perwalian Anak Yang Diminta PPAT Sebagai Syarat Pembuatan Akta Jual Beli Hak Atas Tanah", Jurnal Hukum, 2017, hlm 9.

32 Rachmadi Usman, 2003, Aspek-Aspek Hukum Perbankan Indonesia, Gramedia Pustaka Utama, Jakarta, hlm. 29.

33 Henry Campell Black, 1968, Black's Law Dictionary: Definitions Of The Terms And Phrases Of American And English Jurisprudence, Ancient And Modern, West Publishing Co, St. Paul, Minn, hlm. 1468.
} 
ketekunan yang berlawanan dengan kecerobohan." Lebih lanjut, kehati-hatian (prudence-noun) atau prudent-adj yakni circumspect or judicious in one's dealings ${ }^{34}$ jika dihubungkan dengan bidang investasi maka dikenal dengan istilah prudent-investor rule (dalam trust) yakni the principle that a fiduciary must invest in only those securities or portfolios of securities that a reasonable person would buy. ${ }^{35}$

Dalam industri bisnis dan keuangan, Panaourgias memberikan lingkup terminologi kehati-hatian: Pertama, perlindungan investor, nasabah penyimpan, peserta pasar uang, pembuat kebijakan, atau orang kepada siapa fiduciary duty diutangkan oleh lembaga keuangan. Kedua pemeliharaan terhadap safety, soundness, integritas atau tanggungjawab keuangan dari lembaga keuangan, ketiga menjamin integritas dan stabilitas dari sistem keuangan para pihak ${ }^{36}$.

Prinsip kehati-hatian memiliki makna memberlakukan sikap waspada baik pada diri sendiri maupun bagi orang lain dengan memerhatikan konsekuensi dari setiap tindakan yang dilakukan, baik untuk saat ini maupun di kemudian hari. ${ }^{37}$ Menurut Sri Wartini, prinsip kehati-hatian memiliki tujuan untuk mengantisipasi dan melakukan pencegahan sejak awal terjadinya suatu akibat yang tidak pasti dari suatu kegiatan tertentu yang dilakukan oleh manusia. ${ }^{38}$ Dari beberapa doktrin mengenai prinsip kehati-hatian sebagaimana diuraikan di atas, maka dapat disimpulkan bahwa prinsip kehati-hatian merupakan suatu landasan berpikir yang dipergunakan sebelum melakukan sesuatu dengan terlebih dahulu mempertimbangkan segala kemungkinan agar tidak terjadi permasalahan di kemudian hari. ${ }^{39}$

Apabila dihubungkan dengan lapangan hukum perdata, prinsip kehati-hatian merupakan salah satu faktor utama yang menjadi perhatian dalam merumuskan sebuah kebijakan (produk hukum) terutama yang menyangkut kepentingan pihak luar yang memiliki hak dan kepentingan yang sama. Tujuan utama dari perkara permohonan perwalian orang tua kandung terhadap anak adalah untuk bertindak hukum atas nama anak yang masih di bawah umur terhadap objek warisan orang tuanya yang telah meninggal dunia. Di antara kepentingannya adakalanya untuk penjualan objek waris atau sebagai syarat jaminan kredit di perbankan.

Dalam hal penjualan objek warisan, PPAT atau dalam hal ini notaris mewajibkan adanya penetapan (beschikking) perwalian dari pengadilan sebagai syarat utama untuk mengurus akta jual beli. Oleh karena itu, dalam jual beli mengharuskan para pihak (penjual dan pembeli) harus dalam keadaan cakap hukum. ${ }^{40}$ Adanya penetapan pengadilan sebagai dokumen resmi tertulis berfungsi sebagai bukti bahwa orang tua itu cakap hukum dalam bertindak mewakili kepentingan anak dalam penjualan objek warisan dan disamping itu juga sebagai jaminan bahwa orang tua tidak dalam keadaan pailit dan tidak di bawah pengampuan (idiot).

Adapun dalam hal kepentingannya untuk mendapatkan fasilitas kredit/pinjaman utang,

\footnotetext{
Bryan A. Garner, 2004, Black’s Law Dictionary, Thomson West, St. Paul, hlm. 1263.

Ibid., hlm 1294.

Lihat pendapat Lazaros E. Panaourgias sebagaimana dikutip Paripurna Sugarda, "Kontrak Standar: Antara Prinsip Kehati-Hatian Bank Dan Perlindungan Nasabah Debitur", Jurnal Mimbar Hukum, Vol. 20, No 2, Juni 2008, hlm. 196.

Adam Smith, 1976, The Theory Of Moral Sentiments, Oxford University Press, New York, hlm. 153.

38 Sri Wartini, "Implementasi Prinsip Kehati-hatian Dalam Sanitary And Phythosanitary Agreemant, Studi Kasus: Keputusan Appellate Body WTO Dalam Kasus Hormone Beef Antara Uni Eropa Dengan Amerika Serikat”, Jurnal Hukum, Vol. 14, No. 2, April 2007, hlm. $296-313$.

39 Hatta Isnaini Wahyu Utomo, et al., "Prinsip Kehati-hatian Pejabat Pembuat Akta Tanah dalam Peralihan Tanah Yang Belum Bersertifikat", Jurnal Ius Quia Iustum, Vol. 24, No.3, Juli 2017, hlm. 473.

40 Ada sejumlah legislasi tentang batasan umur anak yang dianggap cakap hukum di antaranya KUHPidana yaitu 16 tahun, UU No. 1 /1974 tentang Perkawinan (18 tahun), UU No. 13/2003 tentang Ketenagakerjaan (18 tahun), UU No. 12/1995 tentang Pemasyarakatan (18 tahun), UU No. 11/2012 tentang Sistem Peradilan Pidana Anak (12 tahun), UU No. 39/1999 tentang Hak Asasi Manusia (18 tahun), UU No. 23/2002 tentang Perlindungan Anak (18 tahun), UU No. 44/2008 tentang Pornografi (18 tahun), UU No. 12/2006 tentang Kewarganegaraan (18 tahun), sedangkan dalam KHI yaitu 21 tahun. Lihat: Hukumonline, "Perbedaan Batasan Usia Cakap Hukum dalam Peraturan Perundang-undangan", https://www.hukumonline.com/klinik/detail/ulasan/lt4eec5db1d36b7/perbedaan-batasan-usia-cakap-hukum-dalam-peraturan-perundangundangan/, diakses 7 Agustus 2019.
} 
biasanya pihak perbankan menjadikan objek waris sebagai agunan (collateral) yang bisa menjamin pelunasan atas utang/kredit tersebut. Salah satu syarat utama objek jaminan tersebut adalah harus dalam keadaan sah dan sempurna kepemilikannya ${ }^{41}$ oleh salah satu subjek hukumnya. Dalam hal kepemilikan objek waris yang masih dikuasai oleh anak di bawah umur, perlu diberikan akses hukum untuk bertindak mewakili kepentingannya, karena anak di bawah umur termasuk kategori subjek yang belum cakap hukum. Untuk itulah pihak perbankan mensyaratkan adanya penetapan pengadilan sebagai bukti tertulis untuk menjamin bahwa segala tindakan atas harta itu sudah beralih kewenangannya kepada orang tua kandung sebagai subjek yang cakap hukum.

Oleh karena praktik peralihan hak atas tanah dan bangunan dan praktik kredit hutang atau pembiayaan di perbankan syariah adalah suatu perbuatan hukum yang urgen dan mengandung konsekuensi yuridis di kemudian hari, maka pihak PPAT (Notaris) maupun pihak perbankan dituntut untuk membangun prinsip kehati-hatian (prudential) di atasnya, karena hal itu menyangkut kepentingan pihak ketiga.

Dasar filosofis eksistensi prinsip kehati-hatian (prudential) pada kegiatan usaha perbankan pada hakikatnya adalah sebagai jaminan kepercayaan masyarakat kepada perbankan karena pada dasarnya perbankan mempunyai tupoksi penting dalam pembangunan ekonomi. Selain fungsi utamanya sebagai intermediary, yang mempertemukan pemilik dana (surplus of fund) dengan pengguna dana (lack of fund), perbankan mempunyai peran strategis dalam mendorong perekonomian negeri, yaitu sebagai agent of development, agent of services dan agent of trust. ${ }^{42}$ Ketiga peran tersebut akan berjalan dengan baik, apabila fungsi intermediary bekerja secara optimal. Bank menjadi alternatif pembiayaan bagi dunia usaha dan berperan menggerakkan perekonomian dengan menggunakan dana yang dipercayakan masyarakat kepada bank, namun jika ketiga hal di atas tidak diperhatikan secara hati-hati, maka potensi kerugian ekonomi akan berdampak sistemik terhadap pembangunan di sektor lainnya.

Berdasarkan penelitian yang dilakukan oleh Lastuti Abu Bakar dan Tri Handayani disimpulkan bahwa implementasi prinsip kehatihatian (prudencial banking principle) memiliki cakupan yang luas, tidak hanya sebatas berkaitan dengan proses pemberian kredit atau pembiayaan berdasarkan prinsip syariah. ${ }^{43}$ Penerapan prinsip kehati-hatian juga berkaitan erat dengan kelembagaan bank, sejak bank didirikan, beroperasi, menerbitkan produk $^{44}$ dan melayani nasabah. Termasuk ke dalam pengertian kelembagaan bank adalah penerapan prinsip kehati-hatian dalam menentukan sumber daya manusia yang memiliki kompetensi. ${ }^{45}$

Sedangkan implementasi prinsip kehatihatian (prudential) yang menyangkut peralihan hak atas tanah dan bangunan bisa ditemukan dalam Peraturan Pemerintah Nomor 24 tahun 2016 tentang Perubahan Peraturan Pemerintah Nomor 37 Tahun 1998 tentang Peraturan Jabatan Pejabat Pembuat Akta Tanah pada Pasal 22 dan 23 yang

41 Dikalangan Fuqaha harta (al-mal) dikenal dua macam yaitu Milk Al-Tam (Kepemilikan Sempurna) dan Milk An-Naqis (Kepemilikan Tidak Penuh). Milk al-Tam yaitu pemilikan yang meliputi bendanya dan manfaatnya sekaligus. Artinya penguasaan terhadap sesuatu yang dimiliki itu mencakup benda dan manfaatnya. Adapun cirinya yaitu pertama pemiliknya bebas menggunakannya dan mengelolanya menurut kehendaknya. Kedua, pemiliknya bebas mengambil manfaat dalam segala segi dan kepentingan asal tidak bertentangan dengan syara'. Ketiga, pemilikan dan pengambilan manfaat itu tidak dibatasi oleh waktu dan tempat tertentu (Ali Al-Khafifi, Mukhtasar Ahkam Al-Muamalah AlSyar'iyyah, hlm. 9 dikutip dari Abd. Salam, 2013, “Konsep Al-Mal Dalam Perspektif Hukum Islam”, Jurnal Al-Mawarid, Edisi IX, hlm 53.

42 Otoritas Jasa Keuangan, 2016, Perbankan-Seri Literasi Keuangan Perguruan Tinggi, Otoritas Jasa Keuangan (OJK), Jakarta, hlm. 6.

43 Pasal 23 Undang-Undang Nomor 21 Tahun 2008 tentang Perbankan Syariah: "untuk memperoleh keyakinan sebagaimana dimaksud pada ayat (1), Bank Syariah dan/atau UUS wajib melakukan penilaian yang saksama terhadap watak, kemampuan, modal, Agunan, dan prospek usaha dari calon Nasabah Penerima Fasilitas".

44 Dalam hal penerbitan produk baru, lembaga keuangan syariah harus menganut prinsip kehati-hatian agar produk baru tersebut sesuai dengan prinsip-prinsip syariah dan terhindar dari praktik-praktik non-halal seperti Riba, Maisir, Tadlis, Gubn, dan sebagainya. Perbankan syariah juga dituntut untuk bersikap loyal dan mentaati segala arahan dan petunjuk dari Dewan Pengawas Syariah (DSN).

45 Lastuti Abu Bakar, et al., "Telaah Yuridis terhadap Implementasi Prinsip Kehatian-hatian Bank Dalam Aktivitas Perbankan Indonesia”, Jurnal De Lega Lata, Vol. 2, No 1, Januari - Juni 2017, hlm. 79-80. 
secara substansi menegaskan bahwa PPAT harus menerapkan praktik kehatian-hatian yang ketat dalam rangka mengurus hal ihwal yang berkaitan dengan pembuatan akta jual beli tanah sehingga akta yang dibuat dapat memberikan jaminan hak atas tanah bagi masyarakat dan tidak terjadi permasalahan di kemudian hari. ${ }^{46}$

PPAT memiliki tugas pokok untuk melaksanakan kegiatan pendaftaran tanah dengan membuat akta sebagai bukti telah dilakukannya perbuatan hukum tertentu mengenai hak atas tanah yang akan dijadikan dasar bagi perubahan data pendaftaran tanah yang diakibatkan oleh perbuatan hukum. ${ }^{47}$ PPAT sebagai Pejabat yang tanda tangannya mampu mengakibatkan terjadinya peralihan hak, sudah sewajarnya PPAT bertindak penuh kehati-hatian dalam melaksanakan tugas jabatannya, karena setiap produk hukum yang ditandatanganinya pasti akan menimbulkan konsekuensi hukum dikemudian hari.

PPAT yang berwenang membuat akta peralihan hak atastanah diharapkan mampu berperan secara profesional dan mampu menjadi konsultan hukum secara mendasar bagi masyarakat pengguna jasanya berkenaan dengan peralihan hak kepemilikan atas tanah, dari sejak membuat kesepakatan-kesepakatan awal sampai dengan dibuatnya akta peralihan hak kepemilikan atas tanah.

Dalam proses pembuatan aktanya, PPAT harus memeriksa dan mencermati dari aspek legalitas baik dari sisi subyek maupun obyek sehingga ketika terformulasi kedalam suatu akta akan mempunyai otentisitas yang sempurna sebagai alat bukti dan meminimalisir potensi risiko hubungan hukum transaksi jual beli dari masyarakat yang melakukannya ${ }^{48}$ Dengan demikian, penerapan prinsip kehati-hatian (prudential) dalam lapangan hukum perdata adalah sesuatu yang mutlak dan menjadi sebuah keharusan, khususnya bagi praktisi perbankan dan pejabat PPAT (Notaris). Adanya penetapan pengadilan (beschikking) dalam kasus perwalian orang tua kandung terhadap anak merupakan bentuk kehati-hatian untuk menghindari problematika yuridis dikemudian hari. Penetapan tersebut secara hukum menjamin orang tua yang tampil menjadi wali bagi anak-anaknya tidak menyalahgunakan hak anak, tidak dalam keadaan pailit dan di bawah pengampuan/idiot, sehingga bebas untuk melakukan semua transaksi keperdataan anak-anaknya.

\section{Kesimpulan}

Berdasarkan hasil penelitian dan pembahasan di atas, maka dapat dirumuskan kesimpulan sebagai berikut: Pertama, adanya perbedaan tentang sebab perwalian antara KUHPerdata dengan UU Perkawinan dan KHI tentang jenis perwalian menurut undang-undang (wettelijke voogdij) merupakan penyebab lahirnya dualisme kekuasaan yaitu kekuasaan sebagai orang tua dan sebagai wali. Adanya perubahan terminologi kekuasaan dari orang tua menjadi wali, disatu sisi mereduksi eksistensi kekuasaan mutlak orang tua terhadap anak, namun disisi lain dapat memberikan aspek kepastian hukum dan sebagai bagian dari prinsip prudential (kehati-hatian) dalam lapangan hukum perdata.

Kedua, menurut UU Perkawinan, orang tua kandung secara otomatis menjadi wali bagi anaknya untuk melakukan tindakan hukum baik di dalam maupun diluar pengadilan, namun ketika hubungan hukum ini bersentuhan dengan kepentingan perbankan dan peralihan hak atas tanah dan bangunan, maka kekuasaan perwalian ini harus dikonkritkan menjadi sebuah dokumen hukum tertulis yang berbentuk penetapan pengadilan. Urgensitas penetapan perwalian ini adalah sebagai

\footnotetext{
46 Hendry Dwicahyo Wanda, et al., "Prinsip Kehati-hatian Pejabat Pembuat Akta Tanah dalam Pengurusan Peralihan Tanah Letter C", AlDaulah: Jurnal Hukum dan Perundangan Islam, Vol. 7, No. 2, Oktober 2017, hlm. 444.

47 Hatta Isnaini Wahyu Utomo, et al., Op.cit., hlm. 474.

48 Pandam Nurwulan, "Aspek Hukum Transaksi Jual Beli Rumah Susun/Apartemen di Daerah Istimewa Yogyakarta Kaitannya dengan Peran Notaris-PPAT”, Jurnal Hukum Ius Quia Iustum, Vol. 22, No.4, Oktober 2015, hlm 674-697.
} 
bukti tertulis yang bisa memberikan aspek kepastian hukum bahwa segala hak keperdataan anak sudah beralih kekuasaannya kepada orang tua sebagai subjek yang cakap hukum dan menjamin bahwa segala tindakan hukum yang dilakukan orang tua atas kepentingan anaknya tidak merugikan hak anak dan pihak lain.

Ketiga, penerapan asas prudential dalam lapangan hukum perdata adalah sesuatu yang mutlak dan menjadi sebuah keharusan bagi pihak perbankan dan PPAT/Notaris. Dalam hal penjualan objek waris, pihak penjual dan pembeli harus dalam keadaan cakap hukum, jika salah satu pihak masih di bawah umur maka harus diberikan akses untuk bertindak hukum melalui penetapan perwalian. Begitu juga dengan syarat objek waris sebagai agunan kredit (collateral) di perbankan harus sempurna kepemilikannya. Dalam hal subjek waris masih di bawah umur, maka kekuasaannya juga harus diberikan akses melalui penetapan perwalian. Oleh karena kedua kondisi keperdataan di atas selalu berhubungan dengan pihak ketiga, maka disinilah letaknya urgensitas prinsip kehati-hatian (prudential) untuk menghindari problematika yuridis dan potensi sengketa di kemudian hari.

\section{DAFTAR PUSTAKA}

\section{A. Buku}

Afandi, Ali, 2000, Hukum Waris, Hukum Keluarga, Hukum Pembuktian, Rineka Cipta, Jakarta.

Black, Henry Campell, 1968, Black's Law Dictionary: Definitions of The Terms And Phrases Of American And English Jurisprudence, Ancient And Modern, West Publishing Co, St. Paul, Minn.

Garner, Bryan A., 2004, Black's Law Dictionary, Thomson West, St. Paul.

Gultom, Maidin, 2008, Perlindungan Hukum Terhadap Anak Dalam Sistem Peradilan Pidana Anak Di Indonesia, Refika Aditama, Bandung.

Harahap, Yahya, 2008, Hukum Acara Perdata Tentang Gugatan, Persidangan, Penyitaan, Pembuktian dan Putusan Pengadilan, Sinar Grafika, Jakarta.

Mugniyah, Jawad, 2000, Fiqh Lima Madzhab, Penerjemah oleh Masykur AB, et al., Lentera Basritama, Jakarta.

Otoritas Jasa Keuangan, 2016, Perbankan-Seri Literasi Keuangan Perguruan Tinggi, Otoritas Jasa Keuangan (OJK), Jakarta.

Sabiq, Sayid, 1980, Fiqih Sunah: Jilid Ke-8, Al Maarif, Bandung.

Soekanto, Soerjono, 2007, Pengantar Penelitian Hukum, UI Press, Jakarta.
Soerodjo, et al., 2002, Kepastian Hukum Hak Atas Tanah di Indonesia, Arkola, Surabaya.

Soemiyati, 1986, Hukum Perkawinan dan UndangUndang Perkawinan (Undang-Undang No. 1 Tahun 1974 tentang Perkawinan), Liberty, Yogyakarta.

Smith,Adam, 1976, The Theoryof Moral Sentiments, Oxford University Press, New York.

Suadi, Amran, 2017, Penyelesaian Sengketa Ekonomi Syariah Teori dan Praktik, Penerbit Kencana, Jakarta.

Subekti, 2003, Pokok-Pokok Hukum Perdata, Intermasa, Jakarta.

Suma, Muhammad Amin, 2005, Hukum Keluarga Islam di Dunia Islam, PT Raja Grafindo Persada, Jakarta.

Triwulan Tutik, Titik, 2006, Pengantar Hukum Perdata di Indonesia, Prestasi Pustaka, Surabaya.

Usman, Rachmadi, 2003, Aspek-Aspek Hukum Perbankan Indonesia, Gramedia Pustaka Utama, Jakarta.

\section{B. Artikel Jurnal}

Abu Bakar, Lastuti, et al., "Telaah Yuridis terhadap Implementasi Prinsip Kehatian-hatian Bank Dalam Aktivitas Perbankan Indonesia", Jurnal De Lega Lata, Vol. 2, No.1, Januari- 
Juni 2017.

Gunakaya, A. Widiada, "Kedudukan "Lex Ne Scripta" Dalam Sistem Hukum Indonesia", Jurnal Wawasan Hukum, Vol. 22, No. 01, Februari 2010.

Ishak, "Perwalian Menurut Konsep Hukum Tertulis", Kanun Jurnal Ilmu Hukum, Vol. 19, No. 03, Agustus 2017.

Kubis, Fernando, "Kekuatan Pembuktian Surat Menurut Hukum Acara Perdata", Jurnal Lex Crimen, Vol. 6, No. 5, Juli 2017.

Lestari, Raissa, "Implementasi Konvensi Internasional Tentang Hak Anak Di Indonesia", JOM FISIP, Vol. 4, No. 2, Oktober 2017.

Nurwulan, Pandam, “Aspek Hukum Transaksi Jual Beli Rumah Susun/Apartemen di Daerah Istimewa Yogyakarta Kaitannya dengan Peran Notaris-PPAT", Jurnal Hukum Ius Quia Iustum, Vol. 22, No. 4, Oktober 2015.

Salam, Abd., "Konsep al-Mal Dalam Perspektif Hukum Islam", Jurnal Al-Mawarid, Edisi IX, 2013.

Savira, Elvita, et al., "Penetapan Perwalian Anak Yang Diminta PPAT Sebagai Syarat Pembuatan Akta Jual Beli Hak Atas Tanah", Jurnal Hukum, 2017.

Sugarda, Paripurna, "Kontrak Standar: Antara Prinsip Kehati-Hatian Bank DanPerlindungan Nasabah Debitur", Mimbar Hukum, Vol. 20, No.2, Juni 2008.

Utomo, Hatta Isnaini Wahyu, et al., "Prinsip Kehatihatian Pejabat Pembuat Akta Tanah dalam Peralihan Tanah Yang Belum Bersertifikat", Jurnal Ius Quia Iustum, Vol. 24 No. 3, Juli 2017.

Wanda, Hendry Dwicahyo, et al., "Prinsip Kehatihatian Pejabat Pembuat Akta Tanah dalam Pengurusan Peralihan Tanah Letter C", AlDaulah: Jurnal Hukum dan Perundangan Islam, Vol. 7, No.2, Oktober 2017.

Wartini, Sri, "Implementasi Prinsip Kehatihatian Dalam Sanitary And Phythosanitary Agreemant, Studi Kasus: Keputusan
Appellate Body WTO Dalam Kasus Hormone Beef Antara Uni Eropa Dengan Amerika Serikat", Jurnal Hukum, Vol. 14, No. 2, April 2007.

Wulandari, Bernadetta T., "Posisi Anak dalam Perkawinan Antar Bangsa dan Berbagai Permasalahan Hukumnya", Jurnal Hukum, Vol. 7, No. 1, Januari - April 2007.

\section{Artikel dalam Antologi dengan Editor}

Sasmitha, Tody, Hukum Perkawinan dan Keluarga, dalam Miru, Ahmadi, (tanpa tahun), Hukum Perdata Materiil dan Formil, USAID, Jakarta.

\section{Internet}

Hukumonline, "Perbedaan Batasan Usia Cakap Hukum dalam Peraturan Perundangundangan", https://www.hukumonline.com/ klinik/detail/ulasan/ lt4eec5db1d36b7/ perbedaaan-batasan-usia-cakap-hukumdalam-peraturan-perundang-undangan/, diakses 7 Agustus 2019.

Lahati, Teddy, "Penetapan Voogdij Bagi Orang Tua", https://badilag.mahkamahagung.go.id/ artikel/publikasi/artikel/penetapan-voogdijbagi-orang-tua-oleh-teddy-lahati-20-10, diakses 5 Agustus 2019.

Legal Consultant Shietra, and Partners, Penetapan Wali Anak Di Bawah Umur Oleh Orang tua, https://www.hukum-hukum.com/2016/11/ penetapan-wali-anak-di bawah-umurterkait-tanah.html, diakses 7 Agustus 2019.

YourDictionary, "Glossary of the Middle East: Glossary of Islam", https://grammar. yourdictionary.com/glossaries/globalcounterrorism/islam.html, diakses 30

Oktober 2019.

\section{E. Peraturan Perundang-undangan}

Kitab Undang-Undang Hukum Perdata (Diumumkan dengan Maklumat tanggal 30 April 1847, Staatsblad Tahun 1847 Nomor 23). 
Undang-Undang Nomor 48 Tahun 2009 tentang Kekuasaan Kehakiman (Lembaran Negara Republik Indonesia tahun 2009 Nomor 157, Tambahan Lembaran Negara Republik Indonesia Nomor 5076).

Undang-Undang Nomor 10 Tahun 1998 tentang Perubahan Atas Undang-Undang Nomor 7 Tahun 1992 tentang Perbankan (Lembaran Negara Republik Indonesia Tahun 1998 Nomor 182, Tambahan Lembaran Negara Republik Indonesia Tahun 1998 Nomor 3790).

Undang-Undang Nomor 21 Tahun 2008 tentang Perbankan Syariah (Lembaran Negara Republik Indonesia Tahun 2008 Nomor 94, Tambahan Lembaran Negara Republik Indonesia Nomor 4867).
Peraturan Pemerintah Nomor 24 Tahun 2016 tentang Perubahan Atas Peraturan Pemerintah Nomor 37 Tahun 1998 tentang Peraturan Jabatan Pejabat Pembuat Akta Tanah (Lembaran Negara Republik Indonesia Tahun 2016 Nomor 120, Tambahan Lembaran Negara Republik Indonesia Nomor 5893).

Instruksi Presiden Nomor 1 Tahun 1991 tentang Penyebarluasan Kompilasi Hukum Islam (Lembaran Lepas Sekretariat Negara Tahun 1991).

\section{F. Putusan Pengadilan}

Penetapan Pengadilan Agama Banjarbaru Nomor 0021/Pdt.P/2014/PA.Bjb. 